\title{
What Affects the Implied Cost of Equity Capital?
}

\author{
Dan Gode \\ Stern School of Business \\ New York University \\ New York, NY 10012 \\ dgode@stern.nyu.edu
}

\author{
Partha Mohanram \\ Stern School of Business \\ New York University \\ New York, NY 10012 \\ pmohanra@stern.nyu.edu
}

February 3, 2001

We thank Jim Ohlson, Stephen Ryan, and seminar participants at the Stern School of Business, New York University for their helpful comments. We are grateful to $\mathrm{I} / \mathrm{B} / \mathrm{E} / \mathrm{S}$ for providing analyst forecast data. 


\title{
What Affects the Implied Cost of Equity Capital?
}

\begin{abstract}
We estimate implied cost of equity capital $\left(r_{e}\right)$ for a sample of firms from 1984 to 1998 using the Ohlson and Juettner (2000) model that does not make restrictive assumptions about clean surplus and payout policies. We find that $r_{e}$ is strongly positively associated with conventional risk factors such as earnings variability, systematic and unsystematic return volatility, and leverage, and is negatively associated with analyst following. These associations are robust to controls for industry membership and to running the regression in changes instead of levels. Our results support the Ohlson-Juettner metric as a robust and appealing measure of $r_{e}$.
\end{abstract}




\section{Introduction}

Understanding how stock prices relate to earnings forecasts is an important aspect of equity analysis. The cost of equity capital $\left(\mathrm{r}_{\mathrm{e}}\right)$ is a summary measure of risk as perceived by equity investors and is the critical link between stock prices and earnings forecasts. Accordingly, measuring $r_{e}$ and identifying the causes of its variation has received considerable attention.

The paper makes two main contributions. First, it tests a new measure of $r_{e}$ that does not suffer from some of the deficiencies of prior measures of $r_{e}$. Second, it provides new evidence regarding the theoretical factors as well as other commonly cited factors that have been used to explain the variation in $r_{e}$. We first provide the motivation and the description of the new measure of $r_{e}$ and then describe the factors that we use to explain the variation in $r_{e}$.

Traditionally, $r_{e}$ has been measured using realized stock returns. However, the weaknesses of using realized returns have been well documented [Miller (1977), Fama and French (1997), Elton (1999), Gebhardt, Lee, and Swaminathan (2001)]. An alternative approach is to infer $r_{e}$ from the current stock price and the future expected dividends. However, dividend forecasts are not directly available as analysts provide only earnings forecasts. Thus, one needs to make assumptions about payout policies to forecast dividends. This is not appealing on two grounds. First, such payout assumptions (typically a full-payout assumption) are rarely empirically descriptive, and second, given the Modigliani-Miller theorem, absent market frictions and asymmetric information, dividend policies should not affect market values. This exercise is further complicated by the fact that since dividend payments affect future earnings, analyst earnings forecasts implicitly depend on their forecasts of dividend policies.

By focusing on value creation (earnings) rather than value distribution (dividends) Ohlson (1995) and Feltham-Ohlson (1995) provide a residual-income valuation model (RIV) that relates earnings and book values to stock prices without making any assumptions about dividend policies. Although mathematically equivalent to the dividend-discount model, RIV is more appealing than the dividend-discounting model in computing $\mathrm{r}_{\mathrm{e}}$ because it maps earnings to stock prices with less restrictive assumptions. Accordingly, researchers have begun to use RIV to 
estimate the implied $r_{e}$ [Botosan (1997), Gebhardt, Lee, and Swaminathan (2001), and Claus and Thomas (1999)], as well as use it as a model for valuation [Dechow, Hutton and Sloan (1999)].

RIV, however, suffers from the following problems pointed out by Ohlson (2000). First, "clean surplus," an assumption necessary to go from discounting dividends to discounting earnings, does not hold on a per share basis. Second, even on a total equity basis, RIV does not work if buying shares is a positive NPV investment from the perspective of "new" shareholders. Third, many accounting rules violate the clean surplus relation. Fourth, analysts do not forecast book values, which are a critical ingredient of RIV. Finally, using the RIV model also requires assumptions about terminal values and the associated assumptions about future return on common equity. Once again, analysts do not directly forecast future return on common equity. Researchers typically assume that the return on equity regresses to industry median after some period of time. Thus, using RIV often results in "too many degrees of freedom" problem.

Using the RIV model in the absence of explicit book value forecasts requires that we infer the implied book value forecasts using a three-step procedure: (a) Forecast dividend payouts based on the history of payouts. (b) Assume clean surplus on a per share basis. (c) Use the EPS forecasts, dividend projections, and clean surplus to arrive at forecasts of book value. Thus, in the absence of explicit book value forecasts, one is forced to forecast dividends, assume clean surplus on a per share basis, and then derive the future book values per share. This negates the conceptual advantages of RIV. A valuation model that does not use book values as its underpinnings is thus more appealing.

Ohlson and Juettner (2000) provide an alternative to RIV. Instead of using book values, the Ohlson-Juettner model uses expected EPS capitalized at $r_{\mathrm{e}}$. The model has the following appealing features: (1) It allows one to work directly with analysts' earnings forecasts, i.e., it "connects" with the analysts' view of the world. (2) It does not require one to forecast dividends beyond the forthcoming period. (3) It does not assume clean surplus on a per share basis and therefore does not suffer from the problems cited in Ohlson (2000). We therefore use the OhlsonJuettner (2000) model to estimate the implied $r_{e}$. In addition to running levels regressions, we 
also examine how changes in $r_{e}$ across time correlate with changes in measures of firm risk as perceived by equity investors.

We find that while $r_{e}$ has declined over 1984-1998 consistent with the decline in risk-free rates $\left(r_{f}\right)$, the risk premium $\left(r_{e}-r_{f}\right)$ has actually increased slightly. There is also a substantial cross sectional variation in $r_{e}$ across industries. Consistent with our hypotheses, we find that risk factors such as systematic risk $(\beta)$, unsystematic risk, variability of accounting measures, and leverage are all positively correlated with $r_{e}$, and the number of analysts is negatively correlated with $r_{e}$. The results hold whether we run the regressions on a pooled sample across firms or on a pooled sample for each year. The results also hold when we use the risk premium $\left(r_{e}-r_{f}\right.$, where $r_{f}$ is the yield on a 10-year Treasury Bond) as the dependent variable. The relationship between return volatility measures and $r_{e}$ continues to be strong even after controlling for industry effects. In contrast, when we use RIV to infer $r_{e}$, the coefficients do not have the expected signs and $\beta$ merely proxies for industry effects.

To test the robustness of our results, we run regressions in changes instead of levels. $r_{e}$ continues to increase with increases in unsystematic risk, variability in accounting measures, and leverage. Changes in systematic risk $(\beta)$ and analyst following, however, do not correlate with changes in $r_{e}$ because $\beta$ and analyst following vary more across firms in an industry, than they vary across time for firms in our sample. Once again, if we use the RIV model to estimate $r_{e}$, the coefficients are not as expected and industry effects dominate.

Overall, the results show that in contrast to the Ohlson (1995) RIV model, the OhlsonJuettner (2000) model provides a more robust and meaningful measure of $r_{e}$ in the sense that $r_{e}$ correlates with the commonly cited risk factors as expected. This supports using the OhlsonJuettner measure for capital budgeting and valuation.

The rest of the paper is organized as follows. Section 2 summarizes the Ohlson-Juettner (2000) model. Section 3 describes the factors that we consider as influencing $r_{e}$. Section 4 describes data and presents summary statistics. Section 5 presents the results. Section 6 summarizes and concludes the paper. 


\section{Model}

We use the Ohlson-and-Juettner (2000) model without modification. We reproduce the relevant aspects of the model below for readers' convenience.

Consider valuation at date 0

$\mathrm{P}_{0}=$ price per share, date $\mathrm{t}=0$

$\mathrm{dps}_{\mathrm{t}}=$ expected dps, date $\mathrm{t}(t \geq 1)$

eps $_{\mathrm{t}}=$ expected eps, date $\mathrm{t}(t \geq 1)$

$r_{e}=R_{e}-1=$ the cost of equity capital, or the discount factor

Assumption A1. $P_{0}=\sum_{t=1}^{\infty} R_{e}^{-t} d p s_{t}$ where $R_{e}>1$ is a fixed constant.

If $\left\{y_{t}\right\}_{t=0}^{\infty}$ is any sequence of numbers that satisfy the mild transversality condition $R_{e}^{-T} y_{T} \rightarrow 0$ as

$T \rightarrow \infty$, then $0=y_{0}+R_{e}^{-1}\left(y_{1}-R_{e} y_{0}\right)+R_{e}^{-2}\left(y_{2}-R_{e} y_{1}\right)+\ldots$

From equations (1) and (2) we get, $P_{0}=y_{0}+\sum_{t=1}^{\infty} R_{e}^{-t}\left(y_{t}+d p s_{t}-R_{e} y_{t-1}\right)$

Let $y_{t}=e p s_{t+1} / r_{e} \quad t=0,1,2 \ldots$

$P_{0}=\frac{e p s_{1}}{r_{e}}+\sum_{t=1}^{\infty} R_{e}^{-t} z_{t} \quad$ where $z_{t} \equiv \frac{1}{r_{e}}\left[e p s_{t+1}+r_{e} d p s_{t}-R_{e} e p s_{t}\right] \quad t=1,2, \ldots$

Assumption A2. The sequence $\left\{z_{t}\right\}_{t=1}^{\infty}$ satisfies $z_{t+1}=\gamma z_{t} t=1,2 \ldots$ where $1 \leq \gamma<R_{e}$ and $z_{1}>0$.

Note that since $z_{1}<0$ is not permissible, this analysis excludes firms whose forthcoming earnings are expected to be negative. The condition $\gamma<R_{e}$ is necessary and sufficient for convergence of $\sum_{t=1}^{\infty} R_{e}^{-t} z_{t}$.

Assumptions A1 and A2 imply the following pricing equation:

$\frac{P_{0}}{e p s_{1}}=\frac{1}{r_{e}} \times \frac{g_{2}-(\gamma-1)}{r_{e}-(\gamma-1)}$ where $=g_{2} \equiv\left(e p s_{2}-e p s_{1}\right) / e p s_{1}+r_{e}\left(d p s_{1} / e p s_{1}\right)$. 
Rearranging, one gets the following: $r_{e}=A+\sqrt{A^{2}+\frac{e p s_{1}}{P_{0}} x\left(\frac{\Delta e p s_{2}}{e p s_{1}}-(\gamma-1)\right)}$ where $A \equiv \frac{1}{2}\left(\gamma-1+\frac{d p s_{1}}{P_{0}}\right)$

For simplicity, we ignore $r\left(d p s_{1} / e p s_{1}\right)$ and assume $g_{2} \equiv\left(e p s_{2}-e p s_{1}\right) / e p s_{1}$. This yields the following expression for the $r_{\mathrm{e}}$.

$$
r_{e}=\frac{\gamma-1}{2}+\sqrt{\left(\frac{\gamma-1}{2}\right)^{2}+\frac{e p s_{1}}{P_{0}} x\left(g_{2}-(\gamma-1)\right)}
$$

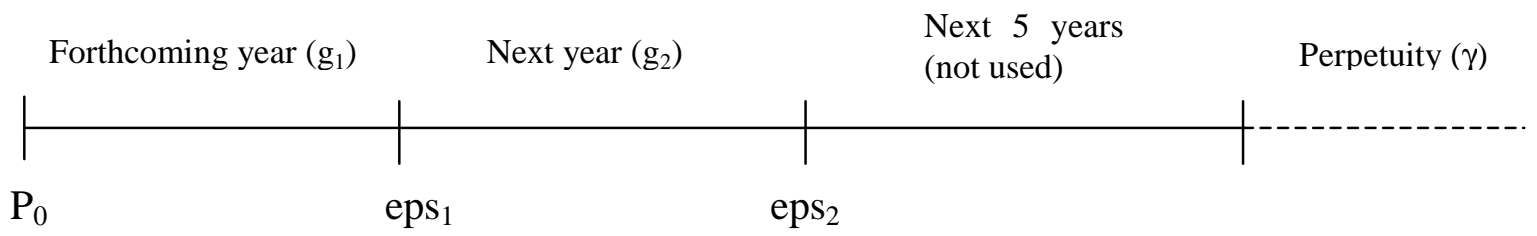

It is important to understand how analyst forecasts map into the Ohlson-Juettner (2000) model. Analysts provide three growth forecasts - earnings growth for the current year, earnings growth for the next year, and annualized earnings growth for the next five years. The OhlsonJuettner model does not directly utilize the 5-year growth forecasts. It may seem that the model ignores information that is readily available, but, in reality, analysts typically set their 5-year forecast close to their next-year forecast and not much additional information can be gleaned from the 5-year forecast. Thus, the Ohlson-Juettner (2000) model expresses $r_{e}$ in terms of the price to forthcoming earnings ratio and short-term and perpetual earnings growth.

Note that the 5-year annualized growth forecast (often called the long-term growth forecast) differs from $\gamma$ in the Ohlson-Juettner (2000) model. $\gamma$ is one plus the perpetual growth rate for a firm and we set it to 1.04, i.e., $4 \%$ perpetual growth. This mirrors the growth rate of the overall economy. Our results are qualitatively unaffected by changes in assumptions of $\gamma$ over a reasonable range.

Since firms disclose quarterly earnings, market expectations are tainted by partial realizations of earnings if we use expectations of annual earnings during the year. To ensure 
comparability across firms, we compute the price-to-forthcoming-earnings ratios only at the beginning of a firm's fiscal year, i.e., we divide the price at the beginning of a fiscal year by the expected forthcoming annual EPS for that year. The expected EPS is thus free of the influence of quarterly disclosures since it extends 1 year from the date of price measurement.

\section{Hypotheses}

Given that $r_{e}$ is a notional concept and can only be inferred from stock prices and stated expectations of the future, one way to rationalize or justify any measure of $r_{e}$ is to study its relationship with those variables that affect a firm's riskiness as perceived by investors. In this section, we describe the factors that we believe affect $r_{e}$. Note that the Ohlson (1995) and Ohlson-Juettner (2000) model make no predictions about the causes of variation in $\mathrm{r}_{\mathrm{e}}$. Our dependent variable is $r_{e}$ as measured using the Ohlson-Juettner (2000) model. To adjust for the effect of changes in risk-free rates, we also use the risk premium $r_{e}-r_{f}$ as the dependent variable, where $\mathrm{r}_{\mathrm{f}}$ is the prevailing yield on the 10-year Treasury bond.

For comparison, we also measure $r_{\mathrm{e}}$ using the residual income valuation model as implemented by Gebhardt, Lee, and Swaminathan (2001), but our paper is different in two major ways. First, we do not use the price-earnings ratio (or market-to-book) as an independent variable to control for market mispricing and anomalies. This is because our dependent variable $\mathrm{r}_{\mathrm{e}}$ determines the PE ratio and therefore using the PE ratio as an independent variable would result in a mis-specified regression. Second, we do not use any controls for growth because we use analysts' earnings growth forecasts to compute $r_{e}$. These differences imply that our paper should not be viewed as a validation/repudiation of Gebhardt, Lee, and Swaminathan (2001). We use their implementation of RIV as it represents the "state of the art" in the literature.

\section{Return Volatility}

We now turn to the factors that affect the variation in $r_{\mathrm{e}}$. The capital asset pricing model predicts a positive association between a firm's $\beta$ and $r_{e}$. We estimate $\beta$ for each firm year 
observation based on a regression of 60 months of lagged monthly returns against the corresponding monthly CRSP value weighted index.

In addition to $\beta$, prior studies have also shown an association between unsystematic risk and future stock returns [Malkiel (1997)]. To extract unsystematic risk from total return volatility we run annual regressions of daily returns against the daily CRSP value weighted index and use the residuals from the regression as a proxy for unsystematic risk.

\section{Information Environment}

Disclosure research has argued that firms that are better "connected" with information intermediaries such as analysts and institutional investors have lower $\mathrm{r}_{\mathrm{e}}$. This is because easy availability of information lowers the information asymmetry between a firm and its investors and lowers the informational risk for investors. Diamond and Verrechia (1991) show theoretically that greater disclosure can lead to greater liquidity, which in turn lowers the costs of capital. Brennan, Jegadeesh and Swaminathan (1993) show that firms with greater analyst coverage are quicker to react to market-wide common information. Botosan (1997) documents a negative association between the level of disclosure and $r_{e}$. Healy, Hutton and Palepu (1998) document that more disclosure can lead to greater liquidity, lower bid-ask spreads, and a lower $\mathrm{r}_{\mathrm{e}}$.

There are a large set of proxies such as number of analysts following a stock, trading volume, bid-ask spreads, and institutional investment that reflect the multi-dimensional nature of information environment. However, Barth and Hutton (1999) and Mohanram (2000) show that these measures are highly correlated with each other and using any one of them suffices. Accordingly, we use the number of analysts as our proxy for information environment and expect a negative association between analyst following and $r_{\mathrm{e}}$.

\section{Earnings Volatility}

There is anecdotal as well as empirical evidence [Barth, Elliott and Finn (1999)] that 
firms that show stable and increasing earnings command a lower $r_{e}$. Gebhardt, Lee, and Swaminathan (2001) focus on the predictability of analyst forecasts to measure earnings volatility. We examine whether firms with a more stable performance as measured by return on assets (ROA), return on equity (ROE), earnings per share (EPS), and EPS growth have lower $\mathrm{r}_{\mathrm{e}}$.

\section{Leverage}

Modigliani and Miller (1958) show that $r_{e}$ should be an increasing function of its leverage. Fama and French (1992) demonstrate a positive association between leverage measured using market value of equity and ex-post stock returns. We expect a positive association between $r_{e}$ and the ratio of the book value of a firm's long-term debt and the market value of its equity.

\section{Industry Effects}

Gebhardt, Lee, and Swaminathan (2001) find that industry effects are the dominant factor in explaining cross sectional differences in $r_{e}$. They find that $\beta$ has no explanatory power when industry dummies are used and they conclude that $\beta$ merely proxies for industry differences in $r_{\mathrm{e}}$. We also include industry controls in our tests by measuring the average of $r_{e}$ as well as the risk premium for all other firms in the same industry as per the Fama-French (1997) classification.

\section{Data and Summary Statistics}

Our sample covers the I/B/E/S data from 1984 to 1998 . We selected those firms that met the following conditions: (1) at least five analyst forecasts per year in $\mathrm{I} / \mathrm{B} / \mathrm{E} / \mathrm{S}$; (2) market capitalization of $\$ 100$ million as of the end of 1998 fiscal year; (3) returns data in CRSP; (4) accounting data in Compustat. We imposed these criteria to ensure adequate and reliable data about analysts' expectations of earnings growth.

Returns data are obtained from the CRSP daily as well as monthly databases. We used daily returns to compute measures of unsystematic risk and used monthly returns to compute $\beta$ for each of the firm-years. Accounting data is obtained from COMPUSTAT's annual database. 
Given that our proxies for firm-specific characteristics rely on accounting information, we use the beginning of a fiscal year as the measurement point for our analysis. This ensures better matching of the independent variables with the dependent variables. We measure the variances of ROA, ROE, EPS, and EPS growth using accounting data from five prior years.

Table 1 provides descriptive statistics for the sample by year. The number of firms increases from 250 in 1984 to 664 in 1998. The mean sales barely increases from approximately $\$ 4.8$ billion in 1984 to just under $\$ 5.5$ billion in 1998 , indicating the greater number of smaller firms in recent years. $r_{e}$ declined substantially over this period, from a mean of $14.80 \%$ in 1984 to $10.26 \%$ in 1998 . However, a large part of this decline can be attributed to the decline in the $\mathrm{r}_{\mathrm{f}}$. The risk-premium $\left(\mathrm{r}_{\mathrm{e}}-\mathrm{r}_{\mathrm{f}}\right)$ actually increased from a mean of $2.78 \%$ in 1984 to a mean of $4.71 \%$ in 1998.

Figure 1-A illustrates the change in mean $r_{e}$ and $r_{e}-r_{f}$ over time. While $r_{e}$ declined over the period, it did not decline as sharply as the decline in $\mathrm{r}_{\mathrm{f}}$. To verify that this is not due to a change in the identity of firms included in the sample, Figure 1-B plots $r_{e}$ and $r_{e}-r_{f}$ for firms that had data for the entire period from 1984-1998. Average $r_{e}$ also declined from $13.30 \%$ to $9.00 \%$, while average risk premium increased from $1.89 \%$ to $3.60 \%$.

Table 2 looks at the distribution of $r_{e}$ and $r_{e}-r_{f}$ across industries in the two extreme years of our analysis. In both years, there is a great diversity in the levels of these variables across the industries. In 1984, industries such as utilities (SIC 49), petroleum (SIC 29) and furniture and fixtures (SIC 25) enjoyed the lowest $r_{e}$, while financial institutions (SIC 60 and 61) faced the highest $r_{e}$. By 1998, there were some significant changes. While utilities continued to have the lowest $r_{e}$, financial institutions (SIC 60 and 61) now have low $r_{e}$ as well. In general, the distribution of industry average $r_{e}$ appears to be much tighter in 1998 . We control for such industry effects by using the mean industry $r_{e}$ and mean industry risk premiums as control variables.

Table 3, Panel A presents the means, standard deviation, and the range of our dependent and explanatory variables. Table 3, Panel B presents Spearman and Pearson correlations between 
these variables. As expected, strong univariate correlations are observed between these variables. Both $r_{e}$ and $r_{e}-r_{f}$ are strongly negatively correlated to the number of analyst estimates (NUMEST). They are also positively correlated to leverage (Debt/Equity), but the correlation is weak. Both measures are also strongly positively correlated to $\beta$ as well as UNSYST (unsystematic risk). This differs from Gebhardt, Lee, and Swaminathan (2001) who find a much

weaker association when they compute $r_{e}$ using RIV. $r_{e}$ and $r_{e}-r_{f}$ are also strongly positively correlated with two of our earnings variance measures - the variance of ROA (ROAVAR) and the variance of ROE (ROEVAR). The correlation with the EPS variance measures and the analyst forecast variance (STDEV) is a bit weaker. Note that ROE and ROA are return measures like $r_{e}$ and are scale independent while EPS does not account for investment and may be scale dependent.

The earnings variance measures are strongly correlated amongst themselves. In addition, the ROA and ROE variance measures appear to be strongly correlated to UNSYST, the unsystematic return variance measure. This is not surprising, as they both measure different aspects of firm specific variance. Factor analysis of the five measures of earnings variability produces a single factor with an eigenvalue of greater than one, which explains slightly more than $52 \%$ of the variance in the variables. The factor loadings are ROAVAR (0.800), ROEVAR (0.844), EPSGRVAR (0.687), EPSVAR (0.689), and STDEV (0.49671). The loadings are strongest on variance of ROA and ROE, which have the highest correlation with $r_{e}$ and $r_{e}-r_{f}$.

\section{Results}

\subsection{Pooled Regressions}

\section{Table 4, Panel B}

Table 4, Panel A presents the results of a pooled regression that uses $r_{e}$ from the OhlsonJuettner (2000) model as the dependent variable. Each observation represents a firm year and the regression is carried out for the entire panel of data from 1984 to 1999 . The t-stats are shown in parentheses beneath the respective coefficients. 
Regression 1 regresses $r_{e}$ against firm characteristics and mean $r_{e}$ for all other firms in the same industry in the same year (INDMEAN: $\mathrm{r}_{\mathrm{e}}$ ). The results strongly support all the hypotheses. NUMEST is strongly negatively associated with $r_{e}$, indicating that firms with greater analyst following face lower $r_{e}$ (or that analysts shy away from risky firms). Both $\beta$ and UNSYST (unsystematic risk) are strongly positively correlated with $r_{e}$ even after controlling for industry effects. The earnings variance measure (EARNVAR) is also positively associated with $r_{e}$, indicating that firms with more variable earnings are penalized through higher $r_{e}$, while firms with more stable earnings have lower $r_{e}$. Leverage (Debt/Equity) is also positively associated with $r_{e}$, which supports Modigliani-Miller (1958) and Fama-French (1992). The industry measure of $r_{e}$ (INDMEAN: $r_{e}$ ) is, not surprisingly, strongly positively associated with $r_{e}$. The regression has an adjusted $\mathrm{R}^{2}$ of $38 \%$.

One potential problem with the regression could be that industry effects dominate the results, both in terms of explanatory power as well as the potential correlations with the other independent variables. To account for this, we run the same regression without the industry control variable in Regression 2. The adjusted $\mathrm{R}^{2}$ does drop, but it is still at around $22.45 \%$. Further, all relationships from regression 1 continue to hold. $\beta$ now has a larger association with $r_{e}$, both in terms of the coefficient (which almost doubles) as well as the significance level. Thus, although there is there is a strong industry-specific component to $\beta$ [regression 2], $\beta$ remains significant even after controlling for industry effects [regression 1].

Regressions 3 and 4 rerun the earlier tests with risk-premium $\left(r_{\mathrm{e}}-\mathrm{r}_{\mathrm{f}}\right)$ as the dependent variable. Regression 3 uses the mean industry risk premium (INDMEAN: $r_{e}-r_{f}$ ) as the control for industry effects. The results are similar to those for $r_{e}$ both in terms of the significance levels of the variables as well as their explanatory power.

\section{Table 4, Panel B}

To compare the Ohlson-Juettner (2000) model with the Ohlson (1995) RIV model, we rerun the regressions in table 4, panel A with $\mathrm{r}_{\mathrm{e}}$ computed using RIV as implemented by Gebhardt, Lee, and Swaminathan (2001). Regression 1 indicates strong industry effects as 
illustrated by the large and significant coefficient for INDMEAN: $\mathrm{r}_{\mathrm{e}}$. The other variables, with the exception of leverage (Debt/Equity), are either not of the hypothesized sign, or not significant. The adjusted $\mathrm{R}^{2}$ drops precipitously from over $45 \%$ to around $9 \%$ if we remove the industry control for industry. However, $\beta$ is now significantly positive as hypothesized. Regressions 3 and 4 present the results for risk premium, which are qualitatively similar.

\subsection{Year-by-Year Regressions}

We also run year-by-year regressions for $r_{e}$ against the independent variables for each of the years from 1984 to 1998 . Table 5 presents the summary coefficients and t-statistics for these regressions using a methodology similar to Fama-MacBeth (1973). Since auto-correlation among the coefficients in the annual regressions can bias the true standard errors downward and bias the t-statistics upward, we correct the t-statistics for auto-correlation as in Bernard (1995). ${ }^{1}$

\section{Table 5, Panel A}

Table 5, Panel A presents regressions when $r_{e}$ is computed using the Ohlson-Juettner model. All of the coefficients have predicted signs and are significant in all four regressions. Removing the control for average $r_{e}$ of other firms in the industry lowers the explanatory power from an average of around $37.6 \%$ to $29.8 \%$. The results for risk premium are also similar.

\section{Table 5, Panel B}

Table 5, Panel B presents regressions when $r_{e}$ is computed using RIV as implemented by Gebhardt, Lee, and Swaminathan. Once again, the coefficients are either not significant, or do not have the expected sign, or vary considerably depending on the regression. Leverage (Debt/Equity) is the only consistently significant variable. As before, when industry controls are removed, one sees a marked drop in the adjusted $R^{2}$.

\footnotetext{
${ }^{1}$ Another alternative is to calculate $\mathrm{Z}$ statistics from the distribution of the t-statistics using information on the actual number of observations in each year-by-year regression. We find similar levels of significance if we use such an approach. We prefer to present the results using our approach as we can better control for the effects of auto-correlation in the coefficients, which can be quite substantial.
} 


\subsection{Changes in Cost of Equity Capital and Risk Premium Across Time}

So far, we have run regressions in levels. Since most of our variables are not scale dependent there is no a priori reason for running the regressions in changes. However, validating the results in a regression in changes provides an additional test for robustness. The time series regressions pose a problem because as shown in table 6, panel A, some of the independent variables are relatively stable across time although they vary significantly in the cross section. To increase the power of our change regressions, we measure the change in variables over the entire period from 1984 to 1998. This also provides us non-overlapping, and therefore independent, observations of the earnings variance, which requires at least five years of data.

\section{Table 6, Panel A}

Table 6, Panel A presents the summary statistics of the variables in 1984 and 1998 for the 200 firms for which we have data in both years. As before, the mean $r_{e}$ declined from around $14.5 \%$ in 1984 to $9.6 \%$ in 1998 , a decline of around $4.9 \%$. However, since $r_{f}$ declined from $11.4 \%$ to $5.30 \%$, the risk premium actually increased from $3.1 \%$ to $4.3 \%$. The number of analysts (NUMEST) has barely changed across this period with a mean of around 16.5. As can be expected, $\beta$ has declined over this period (from a mean of 1.14 to 0.94 ) as these firms have become larger and somewhat more diversified as compared to other firms. However, unsystematic risk (UNSYST) and earnings variance (EARNVAR) increased over this period, indicating that firm specific or unsystematic risk may have actually increased over this period. Leverage (Debt/Equity) declined over this period, though the change was not significant.

\section{Table 6, Panel B}

Table 6, Panel B identifies firms with extreme changes in the underlying variables. Firms are ranked on the independent variables for each of the periods. For each variable, firms that moved up by at least two quartiles (Low to High) and firms that moved down by at least two quartiles (High to Low) are identified. The small number of such firms indicates the relative stability of these variables, at least from an ordinal sense. The numbers are too small for a detailed statistical analysis, but the trends are interesting nonetheless. 
Firms that had a significant increase in analyst following (Low to High for NUMEST) saw a greater decline in $r_{e}$ and smaller increase in risk premium $\left(r_{e}-r_{f}\right)$, indicating the potential effect of the increase in analyst following on lowering $r_{e}$. Firms with the greatest increase in earnings variability (Low to High for EARNVAR) had far less steep declines in $r_{e}$ and much greater increases in $r_{e}-r_{f}$, consistent with their $r_{e}$ increasing with increasing variability in accounting measures. Firms with declining earnings variability actually saw a large drop in risk premium - a possible reward for a reduction in accounting variability. The same trend is seen for unsystematic return variance (UNSYST). This is consistent with penalties for increasing unsystematic risk and closely mirrors the trend for earnings variability. The results for $\beta$ are less clear, with firms with increasing $\beta$ actually seeing greater declines in $r_{e}$ and lesser increase in $\left(r_{e^{-}}\right.$ $r_{f}$ ). As we saw before, $\beta$ is strongly influenced by industry effects, which we do not control for here. The results for leverage are in the direction hypothesized, with firms with the greatest increase in leverage (Low to High) seeing smaller declines in $r_{e}$ and greater increases in $\left(r_{e}-r_{f}\right)$.

\section{Table 7, Panel A}

Table 7 presents the results of regressions with the change in $r_{e}$ as the dependent variable and the changes in the underlying variables as the independent variables. As mentioned above, the changes are measured as the difference between the 1984 levels and the 1998 levels. Even over such a long horizon, there is not much change in some of the explanatory variables for a given firm. This lowers the power of our tests.

Regression 1 has change in $r_{e}\left(\Delta r_{e}\right)$ as the dependent variable and includes controls for average change in $r_{e}$ for other firms in the industry over 1984-1998 (INDMEAN: $\Delta r_{e}$ ). The coefficients for change in earnings variance ( $\triangle \mathrm{EARNVAR})$, change in leverage ( $\triangle \mathrm{Debt} / \mathrm{Equity})$, and change in unsystematic risk ( $\triangle$ UNSYST) are all positive and significant, which is consistent with our predictions. The coefficients for changes in analyst following ( $\triangle$ NUMEST) and change in $\beta(\Delta \beta)$ are insignificant partly because of small relative changes in these variables over time. The adjusted $\mathrm{R}^{2}$ remains high at $30.87 \%$.

Regression 2 is the same as regression 1 without controls for average change in $r_{e}$ for 
other firms in the industry. The results are essentially similar to regression except for a drop in the adjusted $\mathrm{R}^{2}$. Comparison of panel $\mathrm{A}$, table 7 with panel $\mathrm{A}$ in tables 4 and 5 shows that the industry effects are less important in the changes regression than in the levels regression.

Regressions 3 and 4 are the same as regressions 1 and 2 except that the dependent variable is now the change in risk premium $\left(r_{e}-r_{f}\right)$ instead of the change in $r_{e}$. The results are also similar to regressions 1 and 2 further confirming the robustness of the Ohlson-Juettner (2000) measure.

\section{Table 7, Panel B}

Table 7, panel B is similar to table 7, panel A except that panel B uses RIV as implemented by Gebhardt, Lee, and Swaminathan (2001) to estimate $r_{e}$ instead of the OhlsonJuettner (2000) model. The regressions now have a lower explanatory power than the OhlsonJuettner (2000) model and dropping the industry controls (regressions 2 and 4) results in a large drop in adjusted $\mathrm{R}^{2}$. The change in number of analysts ( $\triangle$ NUMEST) is significant and negative, and change in leverage ( $\Delta$ Debt/Equity) is significant and positive, as one would expect. Unsystematic risk ( $\Delta \mathrm{UNSYST})$ and $\Delta \beta$ have negative coefficients, indicating that an increase in these measures of risk reduces cost of capital. The results are hence less clear and consistent in changes for the RIV model than the Ohlson-Juettner (2000) model.

\section{Summary and Conclusions}

Measuring the cost of equity capital $\left(r_{e}\right)$ has received considerable attention because $r_{e}$ is a summary measure of risk as perceived by equity investors. Prior research has predominantly used average realized returns as a measure of $r_{e}$. Recently researchers have used the residual income valuation model (RIV) to compute the implied $r_{e}$. Using RIV is a major improvement over using realized returns, but the RIV model has four major weaknesses as pointed out by Ohlson (2000): (1) the clean surplus relation does not hold on a per-share basis; (2) many recent accounting standards violate the clean surplus relation even on an total equity basis; (3) RIV does not work on a total equity basis if buying shares is a positive NPV investment from the 
perspective of new incoming shareholders; (4) since RIV uses book values as its underpinnings, implementing RIV requires one to forecast book values, which requires one to forecast future dividends. This negates the intellectual appeal of RIV that it does not require dividend forecasts.

Our paper makes four contributions. First, our paper is based upon the Ohlson-Juettner (2000) model that uses analyst earnings forecasts directly to compute implied $r_{e}$, thus obviating the problems inherent in RIV and dividend discounting models. Instead of using historical returns, we are able to use analyst earnings forecasts.

Second, we analyze the impact of the following factors on $r_{e}$ for a sample of firms over the period 1984-1998: systematic risk as measured by $\beta$, unsystematic risk, variability in accounting measures, leverage, and number of analysts following a firm period. These factors are often cited as important determinants of $r_{e}$. Our results confirm our hypothesis that $\beta$, unsystematic risk, earnings variability, and leverage increase $r_{e}$ while greater analyst following lowers $r_{e}$. The relationship of cost of capital with $\beta$ persists even after controlling for industry membership. This differs from Gebhardt, Lee and Swaminathan (2001) who find that systematic risk measures such as $\beta$ merely proxy for industry effects. (Note that our regression specification also differs from their specification.) In that sense, our results lie right in the middle of the "Beta is Useless" vs. "Beta is Everything" debate. The associations between the Ohlson-Juettner (2000) measure of $r_{e}$ and the factors that are typically supposed to drive $r_{e}$ suggest that the OhlsonJuettner (2000) model provides a useful way to measure $r_{e}$ for corporate finance and investment decisions.

Third, since the Ohlson-Juettner (2000) model allows us to directly incorporate priceearnings ratios into the measurement of $r_{e}$, we no longer need to use the price-earnings ratio as an independent variable. This leads to a better specification since the price-earnings ratio is an alternative representation of investors' perception of growth and risk $\left(\mathrm{r}_{\mathrm{e}}\right)$ rather than a factor that determines $r_{e}$.

Finally, we test the robustness of our results by regressing changes in $r_{e}$ on changes in explanatory variables. Since most of our results from the levels regressions continue to hold in 
the changes regression, it provides further support that the Ohlson-Juettner (2000) model provides a robust measure of $r_{e}$ that is a summary representation of risk as perceived by equity investors. 


\section{References}

Barth, Mary E., Elliott, John A.; Finn, Mark W., Market Rewards Associated with Patterns of Increasing Earnings, Journal of Accounting Research, 37(2), Autumn 1999, pages 387-413.

Barth, M., and A. Hutton, Information Intermediaries and the Pricing of Accruals, Working Paper, Stanford/Harvard University, 2000.

Bernard, Victor, 1995, The Feltham-Ohlson Framework: Implications for Empiricists, Contemporary Accounting Research 11, No 2., 733-747

Botosan, Christine, 1997, Disclosure Level And The Cost Of Equity Capital, Accounting Review, 72, 323-50.

Brennan, M. J., N. Jegadeesh, and B. Swaminathan, 1993, Investment Analysis And The Adjustment Of Stock Prices To Common Information, Review of Financial Studies 6, 799-824.

Claus, James and Jacob Thomas, 1999, The Equity Risk Premium Is Much Lower Than You Think It Is: Empirical Estimates From A New Approach, Working Paper, Columbia University.

Dechow, Patricia, Amy Hutton, and Richard Sloan, 1999, An Empirical Assessment Of The Residual Income Valuation Model, Journal of Accounting and Economics 26, 1-34.

Diamond, D. and R. Verrecchia, 1991, Disclosure, Liquidity, And The Cost Of Equity Capital, Journal of Finance 46, 1325-60.

Elton, J., Edwin, 1999, Expected Return, Realized Return, And Asset Pricing Tests, Journal of Finance, Vol. 54, No. 4, 1199-1220.

Fama, Eugene F., and Kenneth R. French, 1992, The Cross-Section Of Expected Stock Returns, Journal of Finance 47, 427-465.

Fama, Eugene F., and Kenneth R. French, 1997, Industry Costs Of Equity, Journal of Financial Economics 43, 153-193.

Fama, Eugene, F., and James MacBeth, 1973, Risk, Return, And Equilibrium: Empirical Tests, Journal of Political Economy 71, 607-636.

Feltham, Gerald A., and James A. Ohlson, 1995, Valuation And Clean Surplus Accounting For Operating And Financial Activities, Contemporary Accounting Research 1, 689-731.

Gebhardt, William, Charles M.C. Lee, and Bhaskaran Swaminathan, 2001, Toward an Implied Cost of Capital, Forthcoming in the Journal of Accounting Research.

Healy, Paul, Amy P. Hutton and Krishna Palepu, 1999, Stock Performance and Intermediation Changes Surrounding Sustained Increases in Disclosure, Contemporary Accounting Research 16. 
Lee, Charles M. C., James Myers, and Bhaskaran Swaminathan, 1999, What Is The Intrinsic Value Of The Dow? Journal of Finance 54, 1693-1741.

Malkiel, Burton G., 1997, Risk And Return Revisited, Journal of Portfolio Management 23, Spring, 9-14.

Miller, Edward M., 1977, Risk, Uncertainty, And Divergence Of Opinion, Journal of Finance 32, 1151-1168.

Modigliani, F., Miller, M.H. (1958). The Cost Of Capital, Corporation Finance And The Theory Of Investment. The American Economic Review Vol. XLVIII, No. 3: 261-297.

Mohanram, P., How Do Young Firms Choose Among Different Modes of Disclosure?, Working Paper, New York University (2000).

Ohlson, James A., 1995, Earnings, Book Values, and Dividends in Equity Valuation, Contemporary Accounting Research Vol. 11 No. 2 (Spring 1995) pp 661-687.

Ohlson, James A. and Juettner-Nauroth, Beate E. Expected EPS and EPS Growth as Determinants of Value, Working Paper, New York University, September 2000. 
Table 1: Descriptive Statistics for Sample

\begin{tabular}{|c|c|c|c|c|c|c|c|c|c|c|c|c|c|}
\hline \multirow[t]{2}{*}{ Year } & \multirow[t]{2}{*}{$\mathrm{N}$} & \multicolumn{2}{|c|}{$r_{\mathrm{e}}$ in $\%$} & \multicolumn{2}{|c|}{$\mathrm{r}_{\mathrm{e}}-\mathrm{r}_{\mathrm{f}}$ in $\%$} & \multicolumn{2}{|c|}{ Assets in millions } & \multicolumn{2}{|c|}{ Sales in millions } & \multicolumn{2}{|c|}{ Market Value in millions } & \multicolumn{2}{|c|}{ Number of Analysts } \\
\hline & & Mean & Median & Mean & Median & Mean & Median & Mean & Median & Mean & Median & Mean & Median \\
\hline 1984 & 250 & 14.80 & 14.23 & 2.78 & 3.42 & 5408.5 & 1617.2 & 4795.7 & 1632.6 & 2553.6 & 1066.3 & 16.0 & 16 \\
\hline 1985 & 232 & 11.96 & 11.69 & 1.87 & 2.25 & 6825.9 & 2301.1 & 5446.1 & 2005.8 & 3447.3 & 1565.2 & 17.5 & 18 \\
\hline 1986 & 254 & 11.55 & 11.04 & 3.34 & 3.81 & 7049.5 & 2174.7 & 5260.3 & 2067.0 & 3768.9 & 1725.7 & 18.9 & 19 \\
\hline 1987 & 255 & 11.34 & 10.90 & 1.80 & 2.27 & 7610.0 & 2086.4 & 5535.7 & 2081.9 & 3741.4 & 1688.8 & 19.1 & 19 \\
\hline 1988 & 277 & 11.43 & 11.09 & 1.97 & 2.32 & 8975.5 & 2616.6 & 6123.0 & 2416.7 & 4063.2 & 1847.8 & 19.2 & 19 \\
\hline 1989 & 306 & 10.67 & 10.65 & 2.51 & 2.57 & 9548.0 & 2566.1 & 6256.0 & 2443.2 & 4916.5 & 2057.9 & 19.6 & 19 \\
\hline 1990 & 344 & 11.49 & 11.08 & 2.63 & 3.10 & 9267.9 & 2339.7 & 6231.7 & 2362.4 & 4448.0 & 1616.8 & 18.8 & 18 \\
\hline 1991 & 373 & 11.86 & 11.03 & 3.36 & 4.15 & 7487.8 & 2160.1 & 5318.5 & 2077.2 & 5391.1 & 1888.0 & 17.5 & 17 \\
\hline 1992 & 417 & 11.29 & 10.82 & 3.53 & 3.99 & 8018.6 & 2206.0 & 5079.7 & 1975.7 & 5175.8 & 1800.7 & 16.4 & 15 \\
\hline 1993 & 442 & 11.00 & 10.56 & 4.31 & 4.73 & 9627.0 & 2354.7 & 5592.7 & 1946.0 & 5437.8 & 2146.1 & 16.7 & 15 \\
\hline 1994 & 485 & 10.82 & 10.58 & 2.68 & 2.92 & 9607.2 & 2254.3 & 5539.4 & 1806.0 & 4972.9 & 1901.0 & 16.5 & 14 \\
\hline 1995 & 498 & 11.09 & 10.85 & 4.70 & 4.89 & 10595.8 & 2509.8 & 6035.4 & 1997.0 & 6705.2 & 2285.6 & 15.8 & 14 \\
\hline 1996 & 552 & 10.64 & 10.40 & 3.68 & 3.91 & 10683.9 & 2611.5 & 6118.0 & 1901.1 & 7719.8 & 2542.2 & 15.4 & 13 \\
\hline 1997 & 628 & 10.67 & 10.41 & 4.29 & 4.53 & 10803.7 & 2211.9 & 6036.5 & 1777.9 & 9415.8 & 2496.1 & 14.1 & 12 \\
\hline 1998 & 664 & 10.26 & 10.03 & 4.71 & 4.92 & 11811.4 & 2486.5 & 5538.3 & 1621.9 & 11038.7 & 2215.8 & 12.7 & 11 \\
\hline
\end{tabular}


Figure 1: Cost of Equity Capital and Risk Premium Across Time

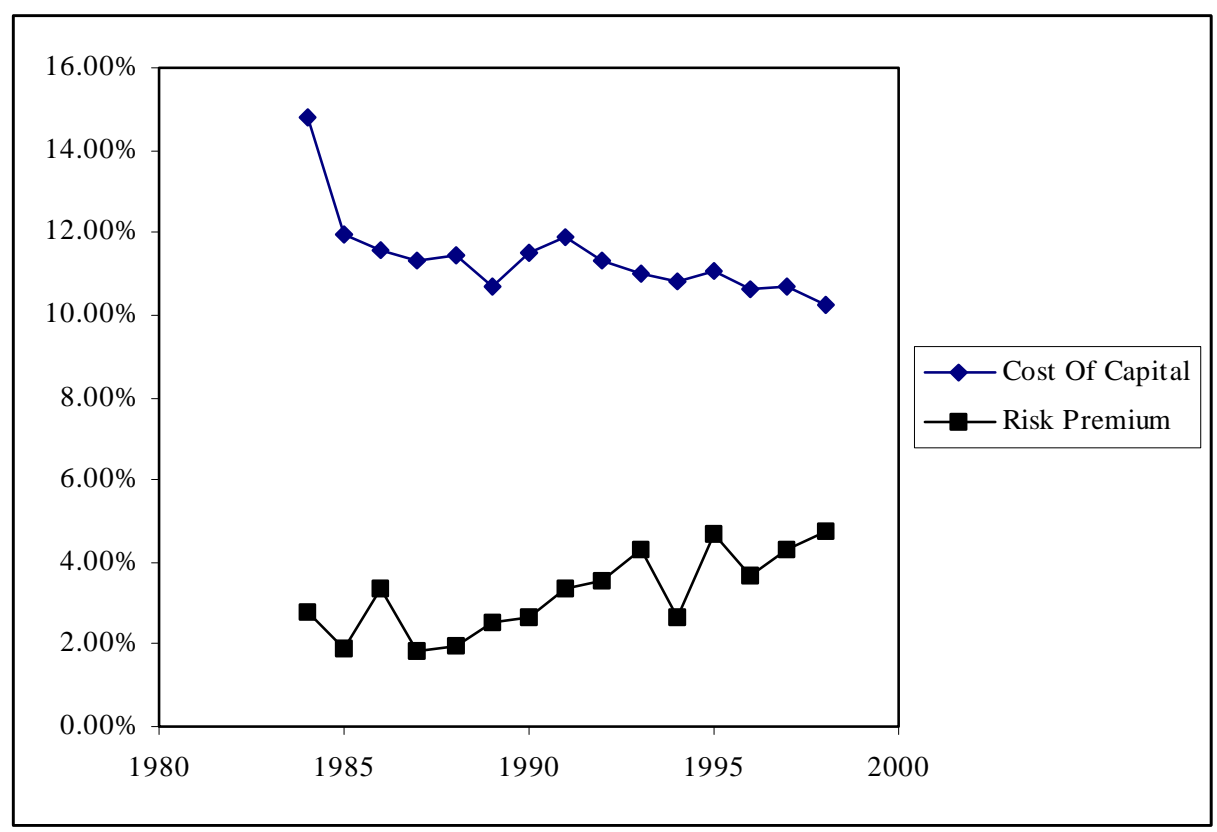

Figure A: All Firms

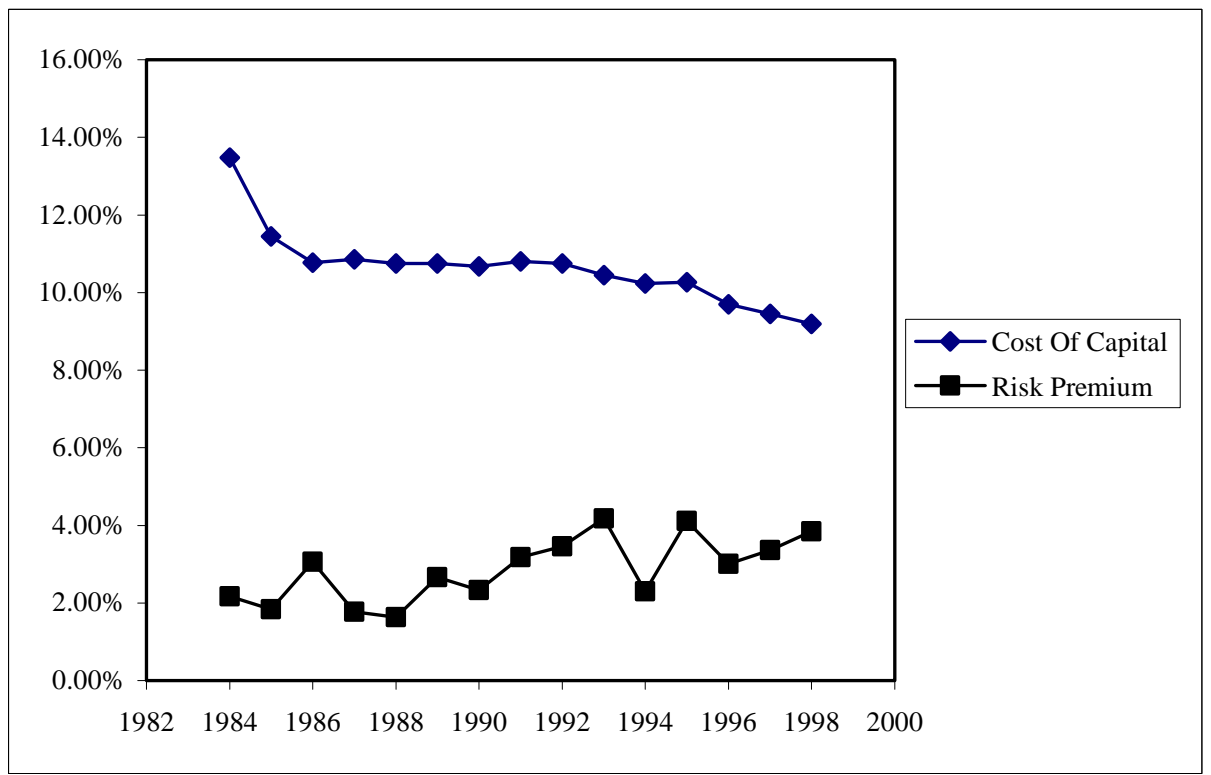

Figure B: Fixed sample from 1984 to 1998

(The subset of firms that had data for all 15 years.) 


\section{Table 2: Cost of Equity Capital and Risk Premium by Industry (2 Digit SIC Codes)}

Industries with at least 5 firms in 1998. Table presents the mean $r_{e}$ and $r_{e}-r_{f}$ for the industries in 1984 and 1999. Since $r_{f}$ is the same for all industries in a given year, $r_{e}-r_{f}$ is provided here for convenience. It does not provide any additional information beyond the cross sectional variation in $r_{e}$. Since the number of firms varies substantially over, it is not meaningful to draw inferences from changes in $r_{e}$ across time. In later tables, we look at changes in $r_{e}$ and $r_{e}-r_{f}$ on a firm-by-firm basis.

\begin{tabular}{|c|l|c|c|c|c|c|c|}
\hline SIC2 & Description & \multicolumn{2}{|c|}{ \# of firms } & \multicolumn{2}{|c|}{$\mathrm{r}_{\mathrm{e}}$ in $\%$} & \multicolumn{2}{c|}{$\mathrm{r}_{\mathrm{e}} \mathrm{r}_{\mathrm{f}}$ in $\%$} \\
\hline & & 1984 & 1998 & 1984 & 1998 & 1984 & 1998 \\
13 & Oil and gas extraction & 6 & 21 & 17.19 & 11.53 & 5.98 & 6.22 \\
15 & General contractors \& operatives & 3 & 8 & 16.64 & 11.70 & 5.23 & 6.37 \\
20 & Food and kindred products & 9 & 19 & 12.52 & 9.00 & 0.71 & 3.60 \\
22 & Textile mill products & 3 & 6 & 12.15 & 10.99 & 0.34 & 5.69 \\
24 & Lumber and wood products & 3 & 7 & 15.55 & 11.87 & 4.34 & 6.51 \\
25 & Furniture and fixtures & 2 & 7 & 9.97 & 10.89 & -1.64 & 5.51 \\
26 & Paper and allied products & 8 & 14 & 16.20 & 12.43 & 4.99 & 7.15 \\
27 & Printing and publishing & 8 & 16 & 12.42 & 9.56 & 1.21 & 4.21 \\
28 & Chemicals and allied products & 35 & 51 & 13.72 & 9.93 & 2.36 & 4.60 \\
29 & Petroleum and coal products & 6 & 12 & 11.83 & 8.03 & 0.33 & 2.74 \\
30 & Rubber and misc. plastics prod & 2 & 6 & 15.01 & 9.67 & 3.80 & 4.39 \\
33 & Primary metal industries & 8 & 15 & 22.70 & 12.04 & 11.39 & 6.69 \\
34 & Fabricated metal products & 4 & 7 & 15.99 & 10.12 & 4.64 & 4.76 \\
35 & Industrial machinery and equip & 16 & 44 & 16.97 & 11.13 & 5.48 & 5.76 \\
36 & Electronic \& other electric eq & 16 & 47 & 14.80 & 12.31 & 3.19 & 6.93 \\
37 & Transportation equipment & 12 & 16 & 18.84 & 10.07 & 7.63 & 4.78 \\
38 & Instruments and related products & 7 & 28 & 14.99 & 11.15 & 3.27 & 5.77 \\
45 & Transportation by air & 5 & 8 & 15.69 & 9.08 & 4.48 & 3.73 \\
48 & Communication & 1 & 10 & 11.74 & 9.76 & 0.53 & 4.47 \\
49 & Electric, gas, and sanitary & 20 & 49 & 9.81 & 6.51 & -1.40 & 1.22 \\
50 & Wholesale trade-durable goods & 6 & 10 & 19.38 & 11.00 & 7.89 & 5.66 \\
51 & Wholesale trade-nondurable & 4 & 7 & 15.84 & 11.43 & 4.34 & 5.99 \\
54 & Food stores & 1 & 5 & 12.18 & 9.39 & 1.03 & 4.00 \\
58 & Eating and drinking places & 2 & 9 & 12.96 & 11.14 & 1.75 & 5.85 \\
60 & Depository institutions & 2 & 60 & 16.56 & 8.88 & 5.35 & 3.58 \\
61 & Nondepository institutions & 2 & 6 & 23.06 & 10.20 & 11.85 & 4.91 \\
62 & Security and commodity brokers & 1 & 5 & 15.79 & 9.39 & 4.58 & 4.10 \\
63 & Insurance carriers & 8 & 35 & 12.68 & 9.60 & 1.47 & 4.31 \\
73 & Business services & 6 & 37 & 15.48 & 11.07 & 3.76 & 5.71 \\
\hline
\end{tabular}




\section{Table 3: Descriptive Statistics for Dependent and Independent Variables}

Values are for a panel of data from 1984 to 1998. Number of firms varies from 250 in 1984 to 664 in 1998.

Panel A: Means and Standard Deviations

\begin{tabular}{lcrrrr}
\hline Variable & $\mathrm{N}$ & \multicolumn{1}{c}{ Mean } & Std Dev & Minimum & Maximum \\
\hline $\mathrm{r}_{\mathrm{e}}$ & 6761 & $11.34 \%$ & $3.21 \%$ & $2.11 \%$ & $31.66 \%$ \\
$\mathrm{r}_{\mathrm{e}}-\mathrm{r}_{\mathrm{f}}$ & 6677 & $4.09 \%$ & $3.27 \%$ & $-7.49 \%$ & $23.04 \%$ \\
$\mathrm{NUMEST}$ & 6761 & 14.95 & 9.208 & 1 & 51 \\
$\beta$ & 6761 & 1.095 & 0.557 & 0.2 & 3 \\
UNSYST & 6748 & 0.0193 & 0.0096 & 0.0017 & 0.0838 \\
Debt/Equity & 6736 & 0.3668 & 1.1486 & 0.0000 & 51.8235 \\
ROAVAR & 5791 & 0.0156 & 0.0166 & 0.0000 & 0.1356 \\
ROEVAR & 5791 & 0.0408 & 0.0505 & 0.0009 & 0.4823 \\
EPSGRVAR & 5737 & 0.5532 & 0.6443 & 0.0045 & 3.3004 \\
EPSVAR & 6016 & 0.6085 & 0.8535 & 0.0154 & 18.8556 \\
STDEV & 6736 & 0.0270 & 0.0372 & 0.0000 & 0.5254 \\
\hline
\end{tabular}

Panel B: Correlations (Figures above diagonal are Pearson correlations and those below are Spearman rank correlations.)

\begin{tabular}{lccccccccccc}
\hline & & & & \multicolumn{1}{c}{ Debt/ } & & & & & & \\
& $r_{\mathrm{e}}$ & $\mathrm{r}_{\mathrm{e}}-\mathrm{r}_{\mathrm{f}}$ & NUMEST & $\beta$ & UNSYST & Equity & ROAVAR ROEVAR & EPSGVAR & EPSVAR & STDEV \\
\hline $\mathrm{r}_{\mathrm{e}}$ & & 0.899 & -0.168 & 0.285 & 0.348 & 0.114 & 0.301 & 0.251 & 0.215 & 0.139 & 0.226 \\
$\mathrm{r}_{\mathrm{e}}-\mathrm{r}_{\mathrm{f}}$ & 0.856 & & -0.255 & 0.265 & 0.471 & 0.080 & 0.335 & 0.296 & 0.260 & 0.112 & 0.221 \\
NUMEST & -0.198 & -0.298 & & -0.030 & -0.378 & -0.003 & -0.096 & -0.104 & -0.067 & 0.141 & -0.018 \\
$\beta$ & 0.330 & 0.273 & 0.025 & & 0.397 & -0.005 & 0.246 & 0.163 & 0.094 & -0.003 & -0.049 \\
UNSYST & 0.420 & 0.535 & -0.423 & 0.346 & & -0.035 & 0.513 & 0.360 & 0.183 & -0.105 & -0.021 \\
Debt/Equity & -0.025 & -0.054 & 0.122 & -0.209 & -0.276 & & -0.070 & 0.009 & 0.058 & 0.076 & 0.128 \\
ROAVAR & 0.350 & 0.363 & -0.077 & 0.196 & 0.449 & -0.198 & & 0.757 & 0.418 & 0.302 & 0.175 \\
ROEVAR & 0.340 & 0.397 & -0.063 & 0.188 & 0.402 & -0.007 & 0.838 & & 0.426 & 0.416 & 0.210 \\
EPSGVAR & 0.257 & 0.328 & -0.067 & 0.128 & 0.257 & 0.145 & 0.586 & 0.695 & & 0.346 & 0.235 \\
EPSVAR & 0.070 & 0.041 & 0.254 & 0.012 & -0.192 & 0.274 & 0.332 & 0.480 & 0.559 & & 0.402 \\
STDEV & 0.120 & 0.143 & -0.044 & -0.131 & -0.029 & 0.374 & 0.212 & 0.276 & 0.339 & 0.380 & \\
\hline
\end{tabular}

Explanation of Variables

\begin{tabular}{ll}
\hline Variable & Explanation \\
\hline $\mathrm{r}_{\mathrm{e}}$ & Cost of equity capital computed using Ohlson-Juettner (2000) model \\
$\mathrm{r}_{\mathrm{e}}-\mathrm{r}_{\mathrm{f}}$ & Risk premium where $\mathrm{r}_{\mathrm{f}}$ is the yield on a 10-year Treasury Bond \\
NUMEST & Number of Analysts Estimates for the most recent observation \\
$\beta$ & $\beta$ computed using 60 months of lagged monthly returns \\
UNSYST & Unsystematic Return Volatility of daily returns in the past year \\
Debt/Equity & Ratio of Long-Term Debt to Market Capitalization \\
ROAVAR & Variance of Return on Assets in the past five years \\
ROEVAR & Variance of Return on Equity in the past five years \\
EPSGVAR & Variance of EPS Growth in the past five years \\
EPSVAR & Variance of EPS in the past five years \\
STDEV & Standard Deviation of Analysts' estimates of EPS. \\
\hline
\end{tabular}


Table 4: Pooled regression for determinants of cost of equity capital

Panel A: Using the Ohlson-Juettner (2000) Model

\begin{tabular}{|c|c|c|c|c|}
\hline & \multicolumn{2}{|c|}{ Dependent Variable: $r_{e}$} & \multicolumn{2}{|c|}{ Dependent Variable: $\left(r_{e}-r_{f}\right)$} \\
\hline Independent Variable & Regression 1 & Regression 2 & Regression 3 & Regression 4 \\
\hline \multirow[t]{2}{*}{ Intercept } & 0.021315 & 0.087405 & 0.001630 & 0.012293 \\
\hline & $(9.719)$ & $(59.707)$ & $(-1.184)$ & $(8.594)$ \\
\hline \multirow[t]{2}{*}{ NUMEST } & -0.00025 & -0.00027 & -0.000307 & -0.000382 \\
\hline & $(-6.573)$ & $(-6.012)$ & $(-7.602)$ & -8.662 \\
\hline \multirow[t]{2}{*}{ EARNVAR } & 0.002473 & 0.002927 & 0.002574 & 0.002983 \\
\hline & $(15.360)$ & $(16.302)$ & $(16.028)$ & $(17.051)$ \\
\hline \multirow[t]{2}{*}{$\beta$} & 0.006313 & 0.013727 & 0.005029 & 0.008577 \\
\hline & $(8.421)$ & $(16.969)$ & $(6.911)$ & (10.910) \\
\hline \multirow[t]{2}{*}{ UNSYST } & 0.615766 & 0.72233 & 0.862630 & 1.259298 \\
\hline & (12.139) & $(12.75)$ & $(16.402)$ & $(22.518)$ \\
\hline \multirow[t]{2}{*}{ Debt/Equity } & 0.003205 & 0.003170 & 0.002877 & 0.002371 \\
\hline & $(11.425)$ & $(10.103)$ & $(10.342)$ & $(7.812)$ \\
\hline \multirow[t]{2}{*}{ INDMEAN: $r_{\mathrm{e}}$} & 0.6697 & & & \\
\hline & $(37.553)$ & & & \\
\hline \multirow[t]{2}{*}{ INDMEAN: $\left(\mathrm{r}_{\mathrm{e}}-\mathrm{r}_{\mathrm{f}}\right)$} & & & 0.5846 & \\
\hline & & & $(32.798)$ & \\
\hline \# of observations & 5620 & 5620 & 5550 & 5550 \\
\hline Adjusted $\mathrm{R}^{2}$ & $38 \%$ & $22.45 \%$ & $40.02 \%$ & $28.39 \%$ \\
\hline
\end{tabular}

Explanation of Variables

\begin{tabular}{ll}
\hline Variable & Explanation \\
\hline $\mathrm{r}_{\mathrm{e}}$ & Cost of equity capital computed using the Ohlson-Juettner (2000) model \\
$\mathrm{r}_{\mathrm{e}}-\mathrm{r}_{\mathrm{f}}$ & Risk premium where $\mathrm{r}_{\mathrm{f}}$ is the yield on a 10-year Treasury Bond \\
NUMEST & Number of Analysts Estimates for the most recent observation \\
EARNVAR & Factor that measures Earnings Variability \\
$\beta$ & $\beta$ computed using 60 months of lagged monthly returns \\
UNSYST & Unsystematic Return Volatility of daily returns in the past year \\
Debt/Equity & Ratio of Long-Term Debt to Market Capitalization \\
INDMEAN: $\mathrm{r}_{\mathrm{e}}$ & Average $\mathrm{r}_{\mathrm{e}}$ of all other firms in the same industry \\
INDMEAN: $\left(\mathrm{r}_{\mathrm{e}}-\mathrm{r}_{\mathrm{f}}\right)$ & Average $\left(\mathrm{r}_{\mathrm{e}}-\mathrm{r}_{\mathrm{f}}\right)$ of all other firms in the same industry \\
\hline
\end{tabular}


Table 4, Panel B: Using the residual income valuation (RIV) model

\begin{tabular}{|c|c|c|c|c|}
\hline \multirow[b]{2}{*}{ Independent Variable } & \multicolumn{2}{|c|}{ Dependent Variable: RIV: $\mathrm{r}_{\mathrm{e}}$} & \multicolumn{2}{|c|}{ Dependent Variable: RIV: $\left(\mathrm{r}_{\mathrm{e}}-\mathrm{r}_{\mathrm{f}}\right)$} \\
\hline & Regression 1 & Regression 2 & Regression 3 & Regression 4 \\
\hline \multirow[t]{2}{*}{ Intercept } & 0.018296 & 0.123331 & 0.009406 & 0.048108 \\
\hline & $(9.719)$ & $(44.266)$ & $(-4.097)$ & (18.744) \\
\hline \multirow[t]{2}{*}{ NUMEST } & 0.00000 & -0.000308 & -0.000030 & -0.000403 \\
\hline & $(-0.075)$ & $(-3.617)$ & -0.450 & $(-5.159)$ \\
\hline \multirow[t]{2}{*}{ EARNVAR } & -0.00247 & -0.001155 & -0.000315 & -0.001191 \\
\hline & $(-0.932)$ & $(-3.333)$ & $(-1.179)$ & $(-3.740)$ \\
\hline \multirow[t]{2}{*}{$\beta$} & 0.000588 & 0.011485 & 0.000930 & 0.006294 \\
\hline & $(-0.496)$ & (7.504) & $(-0.786)$ & $(4.490)$ \\
\hline \multirow[t]{2}{*}{ UNSYST } & -0.179916 & -1.869715 & -0.187125 & -1.348529 \\
\hline & $(-2.065)$ & $(-17.257)$ & $(-2.130)$ & $(-13.369)$ \\
\hline \multirow[t]{2}{*}{ Debt/Equity } & 0.004165 & 0.007135 & 0.004222 & 0.006321 \\
\hline & $(9.281)$ & $(12.221)$ & $(9.429)$ & $(11.876)$ \\
\hline \multirow[t]{2}{*}{ INDMEAN:RIV: $\mathrm{r}_{\mathrm{e}}$} & 0.8420 & & & \\
\hline & $(62.239)$ & & & \\
\hline \multirow[t]{2}{*}{ INDMEAN:RIV:( $\left.\mathrm{r}_{\mathrm{e}}-\mathrm{r}_{\mathrm{f}}\right)$} & & & 0.7781 & \\
\hline & & & $(47.884)$ & \\
\hline \# of observations & 5444 & 5444 & 5377 & 5377 \\
\hline Adjusted $\mathrm{R}^{2}$ & $46.85 \%$ & $9.01 \%$ & $34.68 \%$ & $6.81 \%$ \\
\hline
\end{tabular}

Explanation of Variables

\begin{tabular}{ll}
\hline Variable & Explanation \\
\hline RIV: $r_{\mathrm{e}}$ & Cost of equity capital as computed using the RIV model \\
RIV: $\left(\mathrm{r}_{\mathrm{e}}-\mathrm{r}_{\mathrm{f}}\right)$ & Risk premium where $\mathrm{r}_{\mathrm{f}}$ is the yield on a 10-year Treasury Bond \\
NUMEST & Number of Analysts Estimates for most recent observation \\
EARNVAR & Factor that measures Earnings Variability \\
$\beta$ & $\beta$ computed using 60 months of lagged monthly returns \\
UNSYST & Unsystematic Return Volatility of Daily returns in the past year \\
Debt/Equity & Ratio of Long-Term Debt to Market Capitalization \\
INDMEAN:RIV: $\mathrm{r}_{\mathrm{e}}$ & Average $\mathrm{r}_{\mathrm{e}}$ of all other firms in the same industry \\
INDMEAN:RIV: $:\left(\mathrm{r}_{\mathrm{e}}-\mathrm{r}_{\mathrm{f}}\right)$ & Average $\left(\mathrm{r}_{\mathrm{e}}-\mathrm{r}_{\mathrm{f}}\right)$ of all other firms in the same industry \\
\hline
\end{tabular}




\section{Table 5: Annual Regressions for Determinants of Cost of Equity Capital Measures.}

OLS regressions were separately run using the data for each year from 1984 to 1998 . The table presents the mean coefficients, while the $\mathrm{T}$ statistics are created from the distribution of the coefficients after adjusting for autocorrelation in the coefficients (as in Bernard (1995)). The number of observations ranges from 239 in 1984 to 659 in 1998. Figures in brackets represent T statistics

Panel A: Using the Ohlson-Juettner (2000) Model

\begin{tabular}{|c|c|c|c|c|}
\hline & \multicolumn{2}{|c|}{ Dependent variable: $r_{e}$} & \multicolumn{2}{|c|}{ Dependent variable: $\left(\mathrm{r}_{\mathrm{e}}-\mathrm{r}_{\mathrm{f}}\right)$} \\
\hline Independent Variable & Regression 1 & Regression 2 & Regression 3 & Regression 4 \\
\hline \multirow[t]{2}{*}{ Intercept } & 0.03764 & 0.08246 & -0.00479 & 0.00464 \\
\hline & $(3.832)$ & $(33.973)$ & $(-1.687)$ & (1.24) \\
\hline \multirow[t]{2}{*}{ NUMEST } & -0.0003 & -0.00033 & -0.00029 & -0.00031 \\
\hline & $(-4.112)$ & $(-7.367)$ & $(-3.97)$ & $(-7.157)$ \\
\hline \multirow[t]{2}{*}{ EARNVAR } & 0.002794 & 0.003108 & 0.002854 & 0.003151 \\
\hline & $(6.122)$ & $(9.876)$ & $(6.066)$ & (10.174) \\
\hline \multirow[t]{2}{*}{$\beta$} & 0.007379 & 0.012237 & 0.007215 & 0.012002 \\
\hline & $(3.306)$ & $(6.443)$ & (3.143) & $(6.239)$ \\
\hline \multirow[t]{2}{*}{ UNSYST } & 1.117561 & 1.353006 & 1.101929 & 1.33386 \\
\hline & $(6.414)$ & (14.419) & $(6.26)$ & (14.256) \\
\hline \multirow[t]{2}{*}{ Debt/Equity } & 0.00527 & 0.00469 & 0.005447 & 0.004893 \\
\hline & $(4.403)$ & (4.633) & $(4.49)$ & $(4.823)$ \\
\hline \multirow[t]{2}{*}{ INDMEAN: $\mathrm{r}_{\mathrm{e}}$} & 0.4657 & & & \\
\hline & $(6.189)$ & & & \\
\hline \multirow[t]{2}{*}{ INDMEAN: $\left(r_{e}-r_{f}\right)$} & & & 0.4624 & \\
\hline & & & $(6.04)$ & \\
\hline Average Adjusted $\mathrm{R}^{2}$ & $37.63 \%$ & $29.84 \%$ & $37.24 \%$ & $29.56 \%$ \\
\hline
\end{tabular}

Explanation of Variables

\begin{tabular}{ll}
\hline Variable & Explanation \\
\hline$r_{\mathrm{e}}$ & Cost of equity capital $\left(\mathrm{r}_{\mathrm{e}}\right)$ computed using Ohlson-Juettner $(2000)$ model \\
$\mathrm{r}_{\mathrm{e}}-\mathrm{r}_{\mathrm{f}}$ & Risk premium where $\mathrm{r}_{\mathrm{f}}$ is the yield on a 10-year Treasury Bond \\
NUMEST & Number of Analysts Estimates for the most recent observation \\
EARNVAR & Factor that measures Earnings Variability \\
$\beta$ & $\beta$ computed using 60 months of lagged monthly returns \\
UNSYST & Unsystematic Return Volatility of daily returns in the past year \\
Debt/Equity & Ratio of Long-Term Debt to Market Capitalization \\
INDMEAN: $\mathrm{r}_{\mathrm{e}}$ & Average $\mathrm{r}_{\mathrm{e}}$ of all other firms in the same industry \\
INDMEAN: $\left(\mathrm{r}_{\mathrm{e}}-\mathrm{r}_{\mathrm{f}}\right)$ & Average $\left(\mathrm{r}_{\mathrm{e}}-\mathrm{r}_{\mathrm{f}}\right)$ of all other firms in the same industry \\
\hline
\end{tabular}


Table 5, Panel B: Using the residual income valuation (RIV) model

\begin{tabular}{|c|c|c|c|c|}
\hline \multirow[b]{2}{*}{ Independent Variable } & \multicolumn{2}{|c|}{ Dependent Variable: RIV:( $\left.\mathrm{r}_{\mathrm{e}}\right)$} & \multicolumn{2}{|c|}{ Dependent Variable: RIV: $\left(\mathrm{r}_{\mathrm{e}}-\mathrm{r}_{\mathrm{f}}\right)$} \\
\hline & Regression 1 & Regression 2 & Regression 3 & Regression 4 \\
\hline \multirow[t]{2}{*}{ Intercept } & 0.0424 & 0.1361 & 0.0204 & 0.0582 \\
\hline & (1.117) & $(3.415)$ & $(1.047)$ & $(2.116)$ \\
\hline \multirow[t]{2}{*}{ NUMEST } & 0.00004 & -0.0004 & 0.0000 & -0.0004 \\
\hline & $(0.11)$ & $(-1.431)$ & $(0.167)$ & $(-1.628)$ \\
\hline \multirow[t]{2}{*}{ EARNVAR } & -0.0003 & -0.0009 & -0.0002 & -0.0008 \\
\hline & $(-0.407)$ & $(-1.691)$ & $(-0.356)$ & $(-2.044)$ \\
\hline \multirow[t]{2}{*}{$\beta$} & -0.0044 & -0.0002 & -0.0045 & -0.0004 \\
\hline & $(-2.039)$ & $(-0.046)$ & $(-2.123)$ & $(-0.136)$ \\
\hline \multirow[t]{2}{*}{ UNSYST } & -0.4223 & -1.3286 & -0.4332 & -1.3479 \\
\hline & $(-1.015)$ & $(-1.926)$ & $(-1.01)$ & $(-2.223)$ \\
\hline \multirow[t]{2}{*}{ Debt/Equity } & 0.0053 & 0.0093 & 0.0055 & 0.0095 \\
\hline & $(6.756)$ & $(5.02)$ & $(6.831)$ & $(3.606)$ \\
\hline \multirow[t]{2}{*}{ INDMEAN:RIV: $\mathrm{r}_{\mathrm{e}}$} & 0.7481 & & & \\
\hline & (4.684) & & & \\
\hline \multirow[t]{2}{*}{ INDMEAN:RIV: $\left(r_{e}-r_{f}\right)$} & & & 0.7513 & \\
\hline & & & $(4.733)$ & \\
\hline Average Adjusted $\mathrm{R}^{2}$ & $34.42 \%$ & $8.27 \%$ & $34.60 \%$ & $8.28 \%$ \\
\hline
\end{tabular}

Explanation of Variables

\begin{tabular}{ll}
\hline Variable & Explanation \\
\hline RIV: $\mathrm{r}_{\mathrm{e}}$ & $\mathrm{r}_{\mathrm{e}}$ as computed using the RIV model. \\
RIV: $\left(\mathrm{r}_{\mathrm{e}}-\mathrm{r}_{\mathrm{f}}\right)$ & Risk Premium $=\mathrm{r}_{\mathrm{e}}-\mathrm{r}_{\mathrm{f}}$ (the yield on a 10-year Treasury Bond) \\
NUMEST & Number of Analysts Estimates for most recent observation \\
EARNVAR & Factor that measures Earnings Variability \\
$\beta$ & $\beta$ computed using 60 months of lagged monthly returns \\
UNSYST & Unsystematic Return Volatility of Daily returns in the past year \\
Debt/Equity & Ratio of Long-Term Debt to Market Capitalization \\
INDMEAN:RIV: $\mathrm{r}_{\mathrm{e}}$ & Average $\mathrm{r}_{\mathrm{e}}$ of all other firms in the same industry \\
INDMEAN:RIV: $\left(\mathrm{r}_{\mathrm{e}}-\mathrm{r}_{\mathrm{f}}\right)$ & Average $\left(\mathrm{r}_{\mathrm{e}}-\mathrm{r}_{\mathrm{f}}\right)$ of all other firms in the same industry \\
\hline
\end{tabular}


Table 6: Changes in Underlying Variables over the Time Period

Panel A: Changes in the Means

Data presented for 200 firms with data in 1998 and 1984.

\begin{tabular}{lrrr}
\hline & Mean in 1984 & Mean in 1998 & T Stat \\
\hline $\mathrm{r}_{\mathrm{e}}$ & $14.5 \%$ & $9.6 \%$ & -13.592 \\
$\mathrm{r}_{\mathrm{e}}-\mathrm{r}_{\mathrm{f}}$ & $3.1 \%$ & $4.3 \%$ & 3.194 \\
NUMEST & 16.624 & 16.294 & -0.417 \\
EARNVAR & -0.485 & -0.130 & 1.748 \\
$\beta$ & 1.140 & 0.946 & -3.950 \\
UNSYST & $1.5 \%$ & $1.9 \%$ & 7.348 \\
Debt/Equity & 0.611 & 0.308 & -1.145 \\
RF & $11.40 \%$ & $5.30 \%$ & \\
\hline
\end{tabular}

\section{Panel B: Comparison of Firms with Large Changes in Underlying Variables}

Low to High are those firms that were in the fourth or third quartile of a given variable in 1984 and moved up by at least two quartiles in 1998.

High to Low are those firms that were in the first or second quartile of a given variable in 1984 and moved down by at least two quartiles in 1998 .

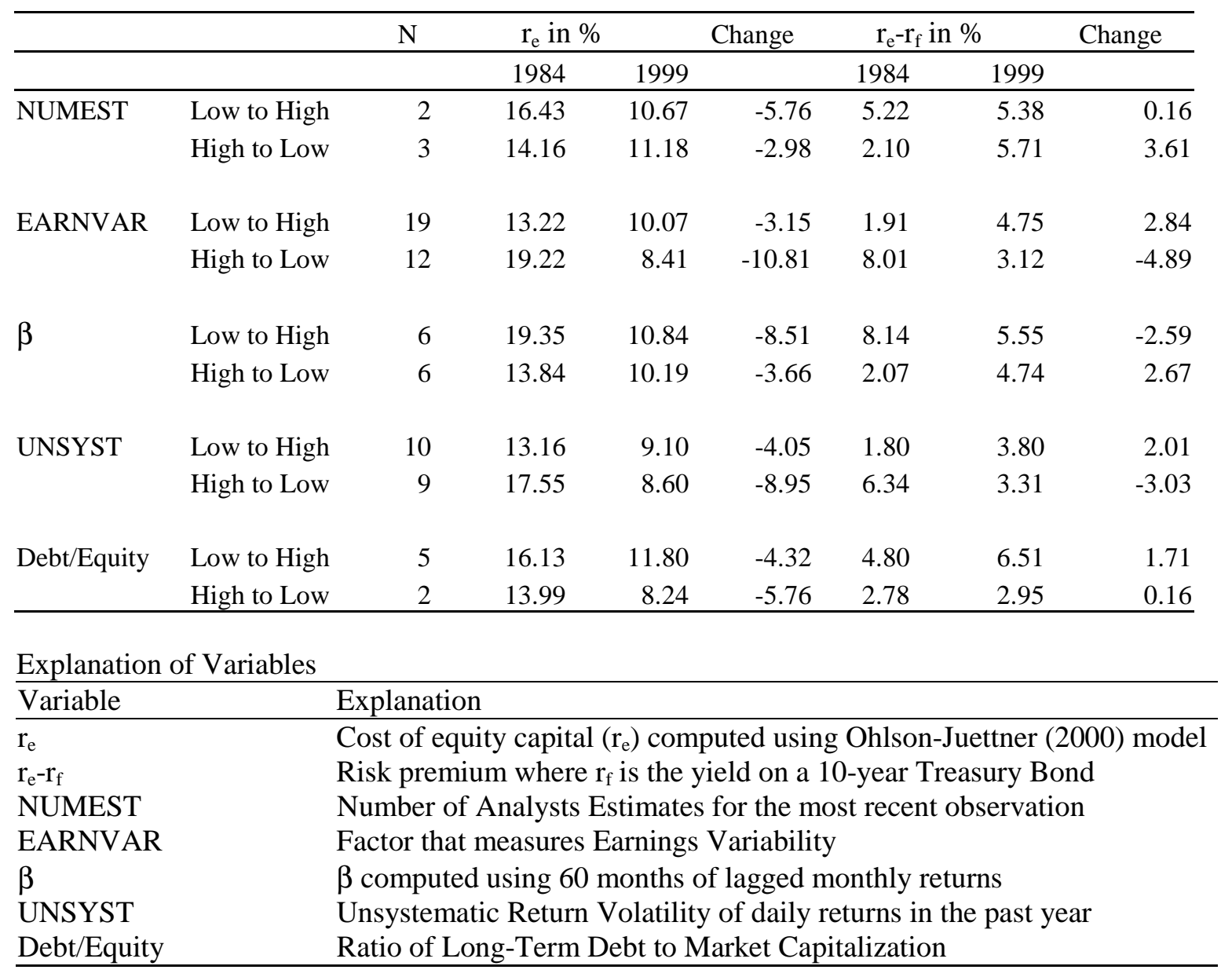


Table 7: Regression of Changes in Cost of equity capital and Risk Premium

\section{Panel A: Using the Ohlson-Juettner (2000) Model}

The dependent variables and independent variables represent the changes in the values of the underlying variables from 1984 to 1998.

\begin{tabular}{|c|c|c|c|c|}
\hline & \multicolumn{2}{|c|}{ Dependent Variable: $\Delta \mathrm{r}_{\mathrm{e}}$} & \multicolumn{2}{|c|}{ Dependent Variable: $\Delta\left(\mathrm{r}_{\mathrm{e}}-\mathrm{r}_{\mathrm{f}}\right)$} \\
\hline Independent Variable & Regression 1 & Regression 2 & Regression 3 & Regression 4 \\
\hline \multirow[t]{2}{*}{ Intercept } & -0.037147 & -0.056210 & -0.003208 & 0.003916 \\
\hline & $(-6.606)$ & $(-15.903)$ & $(-0.811)$ & (1.086) \\
\hline \multirow[t]{2}{*}{$\triangle$ NUMEST } & 0.000298 & 0.000662 & 0.000234 & 0.000627 \\
\hline & $(0.661)$ & $(1.461)$ & $(0.509)$ & $(1.356)$ \\
\hline \multirow[t]{2}{*}{$\triangle \mathrm{EARNVAR}$} & 0.006403 & 0.007158 & 0.006498 & 0.007255 \\
\hline & $(6.285)$ & $(6.938)$ & $(6.266)$ & $(6.893)$ \\
\hline \multirow[t]{2}{*}{$\Delta \beta$} & -0.001685 & -0.001689 & -0.002415 & -0.002725 \\
\hline & $(-0.312)$ & $(-0.315)$ & $(-0.439)$ & $(-0.498)$ \\
\hline \multirow[t]{2}{*}{$\Delta \mathrm{UNSYST}$} & 1.309420 & 1.323128 & 1.382884 & 1.415776 \\
\hline & $(2.917)$ & $(2.865)$ & $(3.023)$ & $(3.005)$ \\
\hline \multirow[t]{2}{*}{$\Delta$ Debt/Equity } & 0.011700 & 0.010879 & 0.011221 & 0.010727 \\
\hline & $(2.213)$ & $(2.001)$ & $(2.084)$ & $(1.934)$ \\
\hline \multirow[t]{2}{*}{ INDMEAN: $\Delta \mathrm{r}_{\mathrm{e}}$} & 0.4329 & & & \\
\hline & $(4.188)$ & & & \\
\hline \multirow[t]{2}{*}{ INDMEAN: $\Delta\left(\mathrm{r}_{\mathrm{e}}-\mathrm{r}_{\mathrm{f}}\right)$} & & & 0.4329 & \\
\hline & & & $(4.226)$ & \\
\hline Observations & 191 & 196 & 191 & 196 \\
\hline Adjusted $\mathrm{R}^{2}$ & $30.87 \%$ & $24.62 \%$ & $30.90 \%$ & $24.50 \%$ \\
\hline
\end{tabular}

Explanation of Variables

\begin{tabular}{ll}
\hline Variable & Explanation \\
\hline$\Delta \mathrm{r}_{\mathrm{e}}$ & Change in $\mathrm{r}_{\mathrm{e}}$ between 1984-1998 computed using the Ohlson-Juettner (2000) model \\
$\Delta\left(\mathrm{r}_{\mathrm{e}}-\mathrm{r}_{\mathrm{f}}\right)$ & Change in $\left(\mathrm{r}_{\mathrm{e}}-\mathrm{r}_{\mathrm{f}}\right)$ between 1984-1998 where $\mathrm{r}_{\mathrm{f}}$ is the yield on a 10-year Treasury Bond \\
$\Delta$ NUMEST & Change in Number of Analysts Estimates between 1984-1998 \\
$\Delta$ EARNVAR & Change in Factor that measures Earnings Variability between 1984-1998 \\
$\Delta \beta$ & Change in $\beta$ computed using 60 months of lagged monthly returns between 1984-1998 \\
$\Delta \mathrm{UNSYST}$ & Change in Unsystematic Return Volatility of Daily returns in the past year between 1984-1998 \\
$\Delta$ Debt/Equity & Change in Ratio of Long-Term Debt to Market Capitalization between 1984-1998 \\
INDMEAN: $\Delta \mathrm{r}_{\mathrm{e}}$ & Average change in $\mathrm{r}_{\mathrm{e}}$ Over 1984-1998 of all other firms in the same industry \\
INDMEAN: $\Delta\left(\mathrm{r}_{\mathrm{e}}-\mathrm{r}_{\mathrm{f}}\right)$ & Average change in $\left(\mathrm{r}_{\mathrm{e}}-\mathrm{r}_{\mathrm{f}}\right)$ over 1984-1998 of all other firms in the same industry \\
\hline
\end{tabular}




\section{Table 7, Panel B: Using the residual income valuation model}

The dependent variables and independent variables represent the changes in the values of the underlying variables from 1984 to 1998.

\begin{tabular}{|c|c|c|c|c|}
\hline & Dependent Var & able: RIV: $\Delta \mathrm{r}_{\mathrm{e}}$ & Dependent Vari & le: RIV: $\Delta\left(\mathrm{r}_{\mathrm{e}}-\mathrm{r}_{\mathrm{f}}\right)$ \\
\hline Independent Variable & Regression 1 & Regression 2 & Regression 3 & Regression 4 \\
\hline Intercept & -0.035116 & -0.113091 & -0.017895 & -0.052966 \\
\hline & $(-2.354)$ & $(-12.706)$ & $(-1.826)$ & $(-5.971)$ \\
\hline$\triangle \mathrm{NUMEST}$ & -0.004484 & -0.004512 & -0.004574 & -0.004548 \\
\hline & $(-4.261)$ & $(-3.953)$ & $(-4.379)$ & $(-3.997)$ \\
\hline$\triangle$ EARNVAR & -0.001848 & -0.003617 & -0.001637 & -0.003520 \\
\hline & $(-0.776)$ & $(-1.392)$ & $(-0.692)$ & $(-1.360)$ \\
\hline$\Delta \beta$ & -0.028344 & -0.014798 & -0.029052 & -0.015835 \\
\hline & $(-2.181)$ & $(-1.095)$ & $(-2.255)$ & $(-1.176)$ \\
\hline$\Delta \mathrm{UNSYST}$ & -1.733871 & -2.480307 & -1.689185 & -2.387659 \\
\hline & $(-1.624)$ & $(-2.133)$ & $(-1.595)$ & $(-2.060)$ \\
\hline$\Delta$ Debt/Equity & 0.032575 & 0.033685 & 0.031806 & 0.033533 \\
\hline & $(2.603)$ & $(2.460)$ & $(2.560)$ & $(2.457)$ \\
\hline INDMEAN:RIV: $\Delta \mathrm{r}_{\mathrm{e}}$ & 0.714229 & & & \\
\hline & $(6.230)$ & & & \\
\hline INDMEAN:RIV: $\Delta\left(\mathrm{r}_{\mathrm{e}}-\mathrm{r}_{\mathrm{f}}\right)$ & & & 0.724008 & \\
\hline & & & $(6.353)$ & \\
\hline Observations & 191 & 196 & 191 & 196 \\
\hline Adjusted $\mathrm{R}^{2}$ & $25 \%$ & $9.65 \%$ & $25.56 \%$ & $9.79 \%$ \\
\hline
\end{tabular}

Explanation of Variables

\begin{tabular}{ll}
\hline Variable & Explanation \\
\hline RIV: $\Delta \mathrm{r}_{\mathrm{e}}$ & Change in $\mathrm{r}_{\mathrm{e}}$ between 1994-1998 as computed using the RIV model \\
RIV: $\Delta\left(\mathrm{r}_{\mathrm{e}}-\mathrm{r}_{\mathrm{f}}\right)$ & Change in $\left(\mathrm{r}_{\mathrm{e}}-\mathrm{r}_{\mathrm{f}}\right)$ between 1994-1998 where $\mathrm{r}_{\mathrm{f}}$ is the yield on a 10-year Treasury Bond \\
$\Delta$ NUMEST & Change in Number of Analysts Estimates between 1984-1998 \\
$\Delta$ EARNVAR & Change in Factor that measures Earnings Variability between 1984-1998 \\
$\Delta \beta$ & Change in $\beta$ computed using 60 months of lagged monthly returns between 1984-1998 \\
$\Delta \mathrm{UNSYST}$ & Change in Unsystematic Return Volatility of Daily returns in the past year between 1984-1998 \\
$\Delta$ Debt/Equity & Change in Ratio of Long-Term Debt to Market Capitalization between 1984-1998 \\
INDMEAN: $\Delta \mathrm{r}_{\mathrm{e}}$ & Average change in $\mathrm{r}_{\mathrm{e}}$ over 1984-1998 of all other firms in the same industry \\
INDMEAN: $\Delta\left(\mathrm{r}_{\mathrm{e}}-\mathrm{r}_{\mathrm{f}}\right)$ & Average change in $\left(\mathrm{r}_{\mathrm{e}}-\mathrm{r}_{\mathrm{f}}\right)$ over 1984-1998 of all other firms in the same industry \\
\hline
\end{tabular}

